\title{
The Role of Drama in Improving Students' English from the Teachers' Perspective
}

\author{
Tahani Refa'at Khalil Bsharat
}

\begin{abstract}
This study sought to find out the role of drama in improving students' English from the of teachers' perspective. To be able to carry out this aim, the researcher used analytical descriptive analysis along with a 20-item questionnaire to collect the necessary. The researcher analyzed the collected data via using SPSS package, means, averages and standard deviations. The study results showed that drama helps students develop self-confidence, enhances cooperation, understanding and, decision making skills. Additionally, drama helps students express imaginative ideas and use language more confidently. Results also showed no statistically significant differences in the role of drama in improving students' English from the teachers' perspective due to the variables of the study (gender and years of experience).Based on these results, the researcher recommended usingmore dramatic activities in the English syllabuses.Workshops and symposiums for teacher training on how to use drama in their teaching practices should be held from time to time.
\end{abstract}

Keywords: Drama, students' English, teachers' perspectives

\section{Introduction}

In the area of drama and theatre and their power in bringing real life, Neelands and Goodle (2000),showed thatthey bring smartly direct experience that is shared when people imagine and behave as if they were other than themselves in some other place at another time. This reflects doing, being or living a normal thing. It is somethingthat we all engage in daily when faced with difficult situations. As a natural means of communications, drama can provide the language learners with meaningful context for speaking and listening such as setting, sole and status, mood, attitude and feeling and shared knowledge.Performance, expression, and cooperation are important life skills that extend far beyond the confines of the theatre (Maley and Duff 1989). As such, educators have long since recognized the crucial role of drama in the school curriculum. According to Falvey and Kennedy (2006) dramatic activities in TESL/TEFL classrooms, have a lot of advantages including expressing feelings verbally and non-verbally, learning English memorably, practicing both linguistic and paralinguistic communication and integrating negotiation with other language skills and subskills into communication. As a significant model of learning, drama is found to be a suitable way of helping children to think about their individual or social problems. Children can learn to explore issues, events and connections, by means of drama. In drama, children draw on their knowledge and experience of the real world in order to create a make believe world, Thus, drama is one of the few areas of the curriculum which is built on dreams and voices. (O'Neill and Lambert, 1989)

\section{Statement of the Problem}

To the researcher's experience in teaching students lack selfconfidence, they are reluctant to speak English and express themselves in an appropriate way. In an attempt to find a solution for these problems, the researcher conducted this study

\section{Purpose of the Study}

This study aimed to examine the role of drama in improving students' English from the teachers' perspectives.

\section{Questions of the Study}

The research seeks to answer the following questions: 1What is the role of drama in improving students' English? 2Are there any significant differences at the $(\alpha=0.05)$ level in the degree using drama in English classrooms related to the variables of (gender and years of experience)?

\section{Significant of the Study}

In thisworld which is characterized by a flux of change in all aspects of life, it became crucial that education can help to cope up with these changes and teachers should vary their teaching methodologies in order to motivate and affect students' attitudes towards learning languages, in our case learning English.In this study, the researcher aimedto highlight that using drama as a teaching tool in the classroom can help bring this wishful change.

\section{Limitations of the Study}

This study took place during the second semester of the scholastic year of 2013/2014. It was applied on teachers of English language in Jenin Directorate of Education

\section{Review of Related Literature}

The researcher classified this part into two are: Drama in education and drama in pedagogy. Let's begin with dram and education: a lot of research was carried out in this area: For example, drama according to Maley and Duff (1978) releases imagination and energy and this could be considered as an educational objective. As for Fernandez and Coil, (1986) drama encourages students to exercise their sensitivity and imagination and thus makes learning more realistic and meaningful.As an educational tool, the use of drama fosters the social, intellectual and the linguistic development of the child (Dougill, 1987). Early and Tarlington (1982) concurs with Dougill and states that drama centers around language development, personal awareness, group co-operation, sensory awareness, and imaginative growth.

In the area of motivation, drama was found to increasestudents' motivation to work better and harder (Mordecai, 1985; Scharengnivel, 1970). Students see the 


\section{International Journal of Science and Research (IJSR) \\ ISSN (Online): 2319-7064}

Index Copernicus Value (2015): 78.96 | Impact Factor (2015): 6.391

need to communicate and concentrates on how to go about a task since drama provides him with a meaningful context.In the aspect of responsible and cooperative learning drama was found to be very useful in this regard. (Early and Tarlington, 1983; Scharengnivel, 1970; Mordecai, 1985). Dramatic activities normally take the form of group work and students cannot afford to stay passive. There is a need to belong to the group and to complete the task. Consequently, students were able to develop a sense of self-worth of themselves as they work together. Drama has a therapeutic effect. It can help solve emotional and behavioral problems (Stern, 1980; Scharengnivel, 1970). It is a way for a 'troublesome kid' to expend his energy and encourage the shy and uncooperative student to participate.

In the aspect of imagination and creativity, Fernandez and CoIl (1986), state that drama encourages students to exercise their sensitivity and imagination. Temporary suspension of the ego occurs when students participate in dramatic activities. They have to perceive an experience through the roles they, take on which are often different from their own. In role-play for example, a student is given a chance to understand and relate to the feelings of others. This develops a sense of empathy in the student as he learns to look beyond himself. Drama develops moral and social qualities in a student (Scharengnivel, 1970).

In the area of pedagogy, many studies were conducted. For example,(Mordecai, 1985 and Athiemoolam 2004) found that drama motivated the teacher to meet the needs of the student;drama activities provide opportunities to understand the thoughts and feelings of the students as they express themselves in the drama activities. From the constant feedback provided by the activities, the teacher can plan better strategies for more effective learning and teaching.Perhaps the value of drama can be summed up by Susan Stern (1980) who looked into drama in second language learning from a psycholinguistic point of view. She stated that drama heightened self-esteem, motivation, spontaneity, increased capacity for empathy, and lowered sensitivity to rejection. All these facilitate communication and provide an appropriate psycholinguistic climate for language learning.According to Via (1985), drama has been used for language teaching since the middle ages. About 10 years ago, many teachers used to scoff at the idea of using drama to teach a second language. The change in attitude towards the use of drama in language teaching came about due to a greater emphasis on meaningful communicative activities instead of mechanical drills.Language is used in meaningful situations (Scharengnivel, 1970; Early and Tarlington, 1982; Mordecai, 1985). Drama contextualizes the language in real or imagined situations in and out of the classroom. Language in the class that uses drama activities is explored, tried out and practised in meaningful situations. Dramatic activities can be used as a means of reinforcement of language learnt (Mordecai, 1985; Fernandez and CoIl, 1986). It helps to extend, retain and reinforce vocabulary and sentence structure through role-play and communication games.

Drama improves oral communication. As a form of communication methodology, drama provides the opportunity for the student to use language meaningfully and appropriately. Maley and Duff (1978) stated that drama puts back some of the forgotten emotional content into language. Appropriacy and meaning are more important than form or structure of the language. Drama can help restore the totality of the situation by reversing the learning process, beginning with meaning and moving towards language form. This makes language learning more meaningful and attempts to prepare the student for real-life situations. Learning a second language can be enjoyable, stimulating and meaningful when combined with drama activities and cultural issues (Mordecai, 1985 and Raba' 2014). The problem of mixed ability is reduced when drama activities are used. Students who are more fluent can take the main roles which require more oral communication, while the weaker students compensate for their lack of linguistic ability by paralinguistic communication e.g. body language and general acting ability (miming).

Earl Stevick (1980), states that language learning must appeal to the creative intuitive aspect of personality as well as the conscious and rational part. Drama activities can be used to provide opportunities for the student to be involved actively. The activities involve the student's whole personality and not merely his mental process. Effective learning takes place as the student involves himself in the tasks and is motivated to use the target language.

Hailat's study (2006) aimed at investigating the effect of using drama on fourth-grade students` achievement in social education as compared to traditional class-teaching method. A random sample of (208) students was chosen from Irbid Directorate of Education schools. The sample was then divided into two groups: the experimental group with (140) students, taught through drama and the control group with (68) students taught through traditional ways of instruction. The results revealed significant differences in achievement, between the two groups in favor of the experimental group. However they did not show any differences attributed to gender or to the interaction between gender and teaching method.

Savela (2009) found out that dramatic activities taught communication, cultural knowledge and social skills. However, the activities that taught the aforementioned remained rather vague. Nevertheless, the activities had useful means of assisting learning. They required students to use imagination and improvisation, drill phrases, and work in role and in real life situations.

Collins (1980) indicated overriding concern with friendly relations and pupil effort in the drama classroom. Interviews suggested pupil concern with movement and talk, but informal and formal observations showed considerable limitations on both, particularly the latter.From the previous literature,appropriate use of drama might meet several important educational needs, goals, but practice showed little sign of this; so the researcher conducted this type of study to provide teachers and learners with purposeful awareness to the countless benefits of using drama in the classroom in the Palestinian context

Methodology and procedures: The researcher used the descriptive statistical method because of its suitability for the purpose of the study. Additionally for data collection, the 


\section{International Journal of Science and Research (IJSR) \\ ISSN (Online): 2319-7064 \\ Index Copernicus Value (2015): 78.96 | Impact Factor (2015): 6.391}

researcher used a 20-item questionnaire which was distributed among the sample of the study. For the data analysis the researcher used (SPSS), along with percentages, means, standard deviations, t-test and One Way ANOVA.

Population of the study: The study population consisted of all teachers of English in primary schools in Jenin Directorate during the second semester of the scholastic year (2013-2014).

Sample of the study: The sample consisted of (31 male and female teachers) in primary schools.

Validity and reliability of the instrument of the study: The questionnaire was reviewed by a group of experts in the field of scientific research. They deleted and rephrased some items until the study instrument reached its final form. The researcher also used Cronbach' Alpha formula to determine the reliability of the instrument. The reliability of the study was $(0.7680)$, which is good and suitable.

Variables of the study: The independent variables: 1. Gender: (Male, Female) 2. Years of Experience: (0-4, 5-10, 10 and more)

Dependent variable: The role of drama in improving students' English from the teachers' perspective. Tables 1, 2 and 3 showed the distribution of the study independent variables respectively.
Table 1: Frequency and percentage of gender Frequency Percent $\mid$ Valid Percent Cumulative Percent

\begin{tabular}{|c|c|c|c|c|}
\hline Male & 12 & 38.7 & 38.7 & 38.7 \\
\hline Female & 19 & 61.3 & 61.3 & 100 \\
\hline Total & 31 & 100 & 100 & \\
\hline
\end{tabular}

This table describes that the highest percent of gender is $(61.3 \%)$ and is related to female teachers which is more than the male teachers' percentage which is $(38.7 \%)$.

Table 2: Frequency and percent for years of experience

\begin{tabular}{|c|c|c|c|}
\hline \multicolumn{2}{|c|}{ years of experience } & Frequency & Percent \\
\hline \multirow{4}{*}{ Valid } & $0-4$ & 19 & 61.3 \\
\cline { 2 - 4 } & 10 -May & 8 & 25.8 \\
\cline { 2 - 4 } & 10 and more & 4 & 12.9 \\
\cline { 2 - 4 } & Total & 31 & 100 \\
\hline
\end{tabular}

Table 2 showed frequency and percentage for the year of experience variable. The table showed that the highest percent is $(61.3 \%)$ for the $(0-4)$ yearsof experience, while teachers whose years of experience is from $(5-10)$ is $(25.8 \%)$ and those of $(10$ - more $)$ received the lowest percent which is $(12.9 \%)$.

\section{Results and Discussion}

To answer the first question of the study," what is the role of drama in improving students' English from the teachers' perspective)?" the researcher used means, percentages and degree level for each item and for the total degree for the questionnaire. Table 4 shows the results.

Table 3: Mean\& standard deviations and degrees on the items of the questionnaire

\begin{tabular}{|c|c|l|c|c|c|}
\hline Tool No. & Rank & \multicolumn{1}{|c|}{ Item } & Mean & Std. Deviation & Degree \\
\hline 1. & $(1)$ & Dramatic activities help students develop self-confidence & 2.90 & 0.39 & High \\
\hline 2. & $(13)$ & Drama enhances cooperation, understanding and, decision making skills. & 2.77 & 0.49 & High \\
\hline 3. & $(6)$ & Drama motivates students to learn English. & 2.77 & 0.42 & High \\
\hline 4. & $(9)$ & Drama Helps students improve their achievement in English. & 2.74 & 0.44 & High \\
\hline 5. & $(7)$ & Drama Gives students more chances to speak English. & 2.74 & 0.51 & High \\
\hline 6. & $(8)$ & Drama Helps students express imaginative ideas & 2.70 & 0.52 & High \\
\hline 7. & $(3)$ & Drama extends the of students' speech. Range of fluency and effectiveness & 2.70 & 0.58 & High \\
\hline 8. & $(2)$ & Drama brings life into the classroom. & 2.70 & 0.58 & High \\
\hline 9. & $(11)$ & Class discussion can improve reading skills better than other activities. & 2.61 & 0.55 & High \\
\hline 10. & $(5)$ & Dramahelps students to understand the world in which they live. & 2.58 & 0.50 & High \\
\hline 11. & $(10)$ & Drama improves a variety of verbal and non-verbal skills. & 2.58 & 0.62 & High \\
\hline 12. & $(12)$ & Drama Builds the self-esteem and communication skills of the students. & 2.54 & 0.67 & High \\
\hline 13. & $(15)$ & Drama helps the teacher introduce the material in untraditional way. & 2.51 & 0.72 & High \\
\hline 14. & $(17)$ & Drama cannot be used all the time. & 2.48 & 0.72 & High \\
\hline 15. & $(19)$ & Drama gives students the opportunity to express their feelings. & 2.41 & 0.80 & High \\
\hline 16. & $(18)$ & Drama is not suitable for all types of teaching and subjects. & 2.38 & 0.80 & High \\
\hline 17. & $(16)$ & Drama takes a lot of time. & 2.35 & 0.83 & High \\
\hline 18. & $(4)$ & Improvisationis excellent preparation for creative writing. & 2.35 & 0.79 & High \\
\hline 19. & $(20)$ & Drama exposes students' talents and attitudes. & 2.32 & 0.74 & Moderate \\
\hline 20. & $(14)$ & Drama increases sense of humor in the classroom. & 2.32 & 0.79 & Moderate \\
\hline & & Total Degree & 2.65 & .40 & High \\
\hline
\end{tabular}

Table 4showed that the highest mean score on the role of drama in improving students' English from the perspective of teachers was for item 1 and it was (2.9032) and this agrees with Neelands and Goodle (2000),Maley and Duff (1989). Next item that received the second high mean score is item 8 which assured that drama brings life into the classroom and this result matches with(Scharengnivel, 1970; Early and Tarlington, 1982; Mordecai, 1985). The third item that received the third high mean score is item 7 which assured that drama extends the of students' speech. Range of fluency and effectiveness and this result agrees withStevick (1980) and Athiemoolam (2004).The fourth high mean score

\section{Volume 6 Issue 1, January 2017 www.ijsr.net}




\section{International Journal of Science and Research (IJSR) \\ ISSN (Online): 2319-7064}

Index Copernicus Value (2015): 78.96 | Impact Factor (2015): 6.391

is attributed to item 18 which show the great effect of dram on enhancing the learners' creative writing. This finding is unique to the present research and could be a rich area for further studies. The fifth high mean score is associated with item 10 which emphasizes that drama helps students to understand the world in which they live. Such finding is in accordance withWessels, (1987).

The sixth and seventh high mean scores are associated with items 5 and 6 respectively and these items showed that drama gives students a better chance to speak English and helps them express imaginative ideas. As for the finding of item 5 , it is unique to the present research, but the result of item 6 is in the line with Fernandez and CoIl (1986). As for the results 14 and 17 the researcher could not find related literature and so they could be rich for further studies either locally or globally.Results which showed that drama helps student build self-esteem and communication skills are in harmony with Fleming (2006) and Munther (2013) who believed that drama in the classroom changes learning method to be more learner-centered, which only operates through active cooperation of the pupils while the teacher becomes just a facilitator. The finding which stated thatdrama is not suitable for all types of teaching and subjects is unique to the present research and requires further studies. The above-mentioned results are for the items that receive high mean scores. The only two items that received moderate degrees are (19 and 20) with mean score of 2.32 for each can be considered unique results for the present research and once again could be rich resources for further studies.

\section{The study hypotheses analysis and discussion}

The First hypothesis: there were no statistical differences at $(\alpha=0.05)$ inthe role of drama in improving students' English from the perspective of teachers due to gender. Table 5 shows the result.

Table 4: Mean Distribution for Gender

\begin{tabular}{|c|c|c|c|c|c|c|}
\hline & Gender & $\mathrm{N}$ & Mean & Std. Deviation & $\mathrm{t}$ & Sig.* $^{*}$ \\
\hline \multirow{2}{*}{ Total Degree } & Male & 12 & 2.74 & 0.47 & 0.910 & 0.370 \\
\cline { 2 - 6 } & Female & 19 & 2.60 & 0.35 & & \\
\hline
\end{tabular}

Regarding the independent sample t- test we accept the hypothesis which is therewere no statistical differences at $(\alpha=0.05)$ in the role of drama in improving students' English from the perspective of teachers due to gender, because thecalculated sig was $(.370)$ which is more than $(\alpha=0.05)$.

The Second hypothesis:there were no statistical differences at $(\alpha=0.05)$ in the role of drama in improving students' English from the perspective of teachers due to years of experiences and table 7 shows the result

Table 5: Mean Distribution for years of experiences

\begin{tabular}{|c|c|c|c|}
\hline Class & $N$ & Mean & Std. Deviation \\
\hline $0-4$ & 19 & 2.71 & 0.43 \\
\hline $5-10$ & 8 & 2.51 & 0.38 \\
\hline 10 and more & 4 & 2.66 & 0.31 \\
\hline Total & 31 & 2.65 & 0.40 \\
\hline
\end{tabular}

Table 7 shows that the highest mean was for teachers whose years of experience were from 0-4. Followed by teachers whose years of experience were from 5-10 while the lowest mean was for those whose years of experience were from 10 and above.

Table 6: One way ANOVA

\begin{tabular}{|c|c|c|c|c|c|}
\hline & $\begin{array}{c}\text { Sum of } \\
\text { Squares }\end{array}$ & Df & $\begin{array}{c}\text { Mean } \\
\text { Square }\end{array}$ & F & Sig. \\
\hline Between Groups & 0.239 & 2 & 0.119 & 0.713 & 0.499 \\
\hline Within Groups & 4.687 & 28 & 0.167 & & \\
\hline Total & 4.925 & 30 & & & \\
\hline
\end{tabular}

According to table above we accept " the Role of Drama in improving students' English from the perspective of teachers according to years' experience because the sig was (0.499) more than $(\alpha=0.05)$ which that mean there is no differences between study sample the Role of Drama in improving students' English.

\section{Conclusions}

From the researcher's experience as a teacher for the primary classes she found that drama has a big rolein improving the researcher's communication with her students and in discovering their talents; drama takes the biggest part that is fun and effective and even students love it and wantmore. Adding to the aforesaid, drama has a big effect in improving students' thinking, self-confidence and shaping their personalities.

\section{Recommendations}

In the light of the study results and findings, the researcher recommended the following:

Teachers should employ drama after taking a practical training in order to take the utmost advantage of it in the classroom and be an effective tool in teaching and learning.Forming English drama clubs and theatre at school, and incorporate it in extracurricular activities at the level of school, directorates or even the Ministry of Education.The researcher also suggested conducting more research on the role of drama on students' and teachers' attitudes towards affecting the learning and the teaching of English.

\section{References}

[1] Abrams, M.H., Harpham, Geoffrey (2013) . A Glossary of Literary Terms, 11 th Ed., Cengage Learning, P. 95.

[2] Auger, Peter (2010).The Anthem Dictionary of Literary Terms and Theory, Anthem Press, P. 3.

[3] Athiemoolam, L(2004).Drama-In-Education and its Effectiveness in English Second/Foreign Language Classes.The First International Language Learning Conference (ILLC) University Sains Malaysia, (16th 18th December 2004).

[4] Barrows, J and Zorin James (1983). Fifteen concise role-plays and how to use them. Forum 21:1, pp.23-27.

[5] Bird, Allan (1972) "The use of drama in language teaching". ELT Journal 33:4, pp.290-96.

[6] Bolton, G. (1985).Changes in Thinking about Drama in Education. Theory into Practice. Vol. XXIV, no. 3, P. 152.

[7] Collins, J (1980). Educational drama in the secondary

\section{Volume 6 Issue 1, January 2017}




\section{International Journal of Science and Research (IJSR) \\ ISSN (Online): 2319-7064 \\ Index Copernicus Value (2015): 78.96 | Impact Factor (2015): 6.391}

school: an investigation of theory and practise, $P h D$ thesis, Newcastle University.

[8] Courtney, R. (1980).The Dramatic Curriculum. London: Heinemann. P. 111.

[9] Crookall, David (1984). The use of non-ELT simulation". ELT Journal 38:4, pp.262-273.

[10] Dass, Birkam K. (ed.) (1984) Communicative Language Teaching. (Anthology Series 14). Singapore: Singapore University Press.

[11]Dougili, John (1987) Drama Activities for Language Teaching. London: Macmillan.

[12] Early, M and Tarlington C (1982). Off stage: Informal drama in language learning". ELT Documents 113.

[13]Ellis, Rid, 1982. Informal and formal approaches to communicative language teaching. ELTJournal36:2, pp.73-81.

[14]Falvey, Peter, Kennedy, Peter (2006) Learning Language Through Literature: A Sourcebook for Teachers of English in Hong Kong, Hong Kong University Press, P. 132.

[15]Fernandez, James (1984) "Communicative Methodology and the Malaysian teacher". Journal Pendidikan dan Pembelajaran, 1:1, pp.6-10.

[16] Fernandez, L. and Coil, A. (1986). Drama in the classroom. Practical Teaching 6:3, pp.18-21.

[17]Fleming, Mike (2006). Drama and language teaching: The relevance of Wittgenstein's concept of language games. Humanizing language teaching. Issue 4.

[18] Galarcep, M.F. (1971) Puppets in teaching English. ELT Journal 25:2, pp167-170.

[19] Gossin, Pamela (2002). Encyclopedia of Literature and Science, Greenwood Publishing Group, P. 112.

[20] Harmer, Jeremy (1982). What is communicative? ELT Journal 36:3, pp.164-168.

[21] Holden, Susan (1981) Drama in Language Teaching. England: Longman.

[22] Holden, Susan (1983). Role-play and simulation. Second Selection from Modern English Teachers. London: Longman, pp.89-102.

[23] Jones, Ken (1980) Simulations: A Handbook for Teachers. London: Kegan Paul.

[24] Johnson, K. and Morrow K. (1971) Communication in the Classroom. London: Longman.

[25] Hailat, S (2006). The Effect of Drama on Fourth-Grade Students' Achievement in Social Education. The Jordanian Journal of Educational sciences, Vol. 2, Issue 3, 189-199.

[26] Li Xiaoju, (1984). In defense of the communicative approach. . ELT Journal 38:1 pp.2-31.

[27]Littlewood, W. (1984) Communicative Language Teaching. Cambridge: Cambridge University Press.

[28] Livingstone, Carol (1983) Role-play in Language Learning. Singapore: Longman.

[29]Long, M. and Castanos F. (1976). Mime in the classroom. Practical Teaching 6:3 pp.18-21.

[30] Maley, A and Alan D(1982). Drama techniques: a Resource Book of Communication Activities for Language Teachers. 2nd ed. Cambridge: Cambridge University Press.

[31] Maley, Alan (1983). A room full of human beings. Guidelines-Drama, 5:2, pp.1-12.

[32] McGregor, L. (1976). Developments in Drama Teaching. London: open Books, P. 106.
[33] Medges, P (1986). Queries for a communicative teacher". ELT Journal 40:2, pp.107-112.

[34] Mordecai, J (1985). Drama and second language learning". Spoken English, 18:2, pp.12-15.

[35] Moss, W. (1971) "The play's the thing". ELT Journal, 25:2 pp.161-164.

[36] O'Neill, C.and A. Lambert. (1989): Drama Structures. A Practical Handbook for Teachers. London: Hutchinson. P.11.

[37]Raba' Ahmed Awad (2014). The Importance of Integrating the Target Culture in English Language Teaching from the Teacher's Perspectives. Jamia' Vol 81, issue 8 pp1-30. Al-Qasemi Academy - Academic College of Education. Baqa al-Gharbiyye, 30100, Israel

[38]Raj, D (1984). Communicative methodology. Journal Pendidikan dan Pembelajaran, 1:1 pp.1-5.

[39]Redington, C. (1984) Can Theatre Teach? Oxford: Pergamon Press.

[40]Richards, J (1985) "Conversational competence through roleplay". RELC Journal l6:1, pp.82-100.

[41] Swan, M (1985).A critical look at the communicative approach: (I) \& (II)". ELT Journal 39:1, pp.2-12. 39:2, pp.76-87.

[42] Savela, Jarmo, (2009) Drama Education in English Teaching: A study of drama activities in English language schoolbooks", thesis, University of Jyvaskyla.

[43] Smith J, Herring, J and Daniel (1993). Using Drama in the Classroom, READING HORIZONS, volume 33, \#5, P. 419-420.

[44] Turc, Lewis, (1999). The Book of Literary Terms: The Genres of Fiction, Drama, Nonfiction, Literary Criticism, and Scholarship, UPNEP. 81.

[45]Ur, Penny (1981). Task-centered fluency practice. Cambridge: Cambridge University Press.

[46] Ustundag, T(1994). Drama in Contemporary Education. Education in Life. November/ December, vol.37, P .8-9.

[47] Venugopal, Shanta (1986). The use of drama in ELT: A perspective. The English Teacher, Journal 15:1, pp.4148.

[48] Way, B. (1967). Development through drama. Atlantic Highlands, NJ: Humanities Press.

[49] Wessels, C (1987). Drama. Oxford: Oxford University Press. 